CLINICAL STUDY

\title{
Reduced appetite and body mass index with delayed puberty in a mother and son: association with a rare novel sequence variant in the leptin gene
}

\author{
P G Murray ${ }^{1}$, A Read ${ }^{1}$, I Banerjee ${ }^{2}$, A J Whatmore ${ }^{1}$, L E Pritchard ${ }^{1,5}$, R A Davies ${ }^{3}$, J Brennand ${ }^{3}$, A White ${ }^{1,5}$, \\ R J Ross ${ }^{4}$ and P E Clayton ${ }^{1,2}$ \\ ${ }^{1}$ Manchester Academic Health Sciences Centre, University of Manchester, Manchester M13 9WL, UK, ${ }^{2}$ Endocrinology and Diabetes Group, Department of \\ Paediatric Endocrinology, Royal Manchester Children's Hospital, University of Manchester, 5th Floor Research, Oxford Road, Manchester M13 9WL, UK, \\ ${ }^{3}$ AstraZeneca, Alderly Edge, Cheshire SK10 4TG, UK, ${ }^{4}$ Academic Unit of Diabetes, Endocrinology and Reproduction, University of Sheffield, Sheffield \\ S10 2F, UK and ${ }^{5}$ Faculties of Life Sciences and Medical and Human Sciences, University of Manchester, Manchester M13 9PL, UK
}

(Correspondence should be addressed to P E Clayton at Endocrinology and Diabetes Group, Department of Paediatric Endocrinology, Royal Manchester Children’s Hospital, University of Manchester; Email: peter.clayton@manchester.ac.uk)

\begin{abstract}
Introduction: Leptin deficiency caused by mutations within the leptin gene (LEP) results in severe early onset obesity, hypogonadism, pubertal delay and immune system abnormalities. Constitutional delay in growth and puberty (CDGP) is a common condition seen in paediatric clinics, in which children present with delayed growth and puberty but usually also have a slim body habitus. We hypothesized that LEP variants may play a role in the phenotype seen in CDGP.

Aim: To screen a group of children with CDGP for pathogenic sequence variants in LEP.

Patients and methods: Denaturing HPLC was used to screen for LEP sequence variants in DNA samples from 78 children with CDGP (predominantly white males) and 112 control subjects. DNA fragments with a WAVE pattern deviant from wild type were directly sequenced. A STAT3 luciferase reporter assay in human embryonic kidney (HEK293) cells transiently transfected with the leptin receptor was used to test activity of mutant leptin.

Results: One child with CDGP was identified to be heterozygous for a novel missense variant (c.68C > G), which results in a proline to arginine substitution (p.P23R). This sequence variant was not identified in any of the other control subjects, but was identified in his mother who shared a similar phenotype of slim body habitus, reduced appetite and pubertal delay (menarche aged 15 years). The leptin variant showed similar stability in serum compared with wild type and did not demonstrate increased activity in an in vitro reporter gene assay.

Conclusions: This is the first report of a sequence variant within the LEP gene associated with reduced body mass index rather than obesity. We hypothesize that this variant has increased bioactivity in vivo.
\end{abstract}

European Journal of Endocrinology $164521-527$

\section{Introduction}

Leptin is a $16 \mathrm{kDa}$ adipocyte-derived hormone, which plays a central role in regulating body weight both in man and mouse by inhibiting food intake and increasing energy expenditure (1). The leptin gene $(L E P)$ is located at chromosome $7 \mathrm{q} 13$, spans $20 \mathrm{kbp}$ and contains three exons (2). LEP expression is associated with obesity, is induced by insulin, tumour necrosis factor- $\alpha$ and glucocorticoids and is negatively regulated by $\beta$-adrenoreceptor agonists and thiazolidinediones (3). Congenital leptin deficiency conferred by homozygosity for LEP mutations leading to a reduced function is associated with hypogonadotrophic hypogonadism, hyperinsulinaemia and abnormalities of cellular immune function with changes in both the number and function of $\mathrm{T}$ cells (4-6). Treatment with recombinant human leptin in children with congenital leptin deficiency dramatically reduces fat mass, facilitates increased gonadotrophin secretion and pubertal progression and increases $\mathrm{T}$ cell number, cytokine production and proliferation (7).

Constitutional delay in growth and puberty (CDGP) is one of the commonest reasons for referral to a paediatric endocrinologist, is more common in boys and is associated with a variable degree of growth retardation and pubertal delay due to delayed maturation of the hypothalamo-pituitary-gonadal axis (8). Children with CDGP have reduced body mass index (BMI) compared with control subjects (9). A number of families with CDGP show a dominant pattern of inheritance and estimates of the heritability of CDGP suggest $50-80 \%$ of the variance in pubertal onset may be genetically controlled (10). The altered puberty and 
body habitus led us to hypothesize that sequence variants in LEP may affect the phenotype in children with CDGP. Previously, we reported the results of screening a group of CDGP children for known polymorphisms within LEP and screening for novel LEP sequence variants in a small subset of this group $(n=30)$. The known polymorphisms were not associated with CDGP, but homozygosity for the $3^{\prime}$ CTTT short repeat was associated with an increased BMI SDS in this CDGP group (9). We now report the identification of a novel missense sequence variant within LEP found by screening the whole group of children with CDGP for novel variants within the LEP gene, and describe investigations to define its function.

\section{Methods}

\section{Patients}

Ethical approval was obtained from the local NHS and the University of Manchester Research ethics committees and the study adhered to the rules of the Declaration of Helsinki. Informed consent was obtained from the parent in all cases. All children were examined by a consultant paediatric endocrinologist in an outpatient clinic in Manchester, UK and were recruited if the diagnosis reached was CDGP. The notes of each child were reviewed to confirm the diagnosis. Inclusion criteria were

i. Evidence of delayed puberty - lack of breast development (Tanner stage 2) by the age of 12 years in girls or testicular volume $<4 \mathrm{ml}$ by age of 13 in boys.

ii. Evidence of slowing of growth on longitudinal measurements plotted on a growth chart.

iii. No other identifiable cause of delayed puberty or growth impairment from history or investigations.

\section{DNA extraction, heteroduplex WAVE analysis and sequencing}

DNA was obtained from buccal cells from children and parents and extracted using standard methods. Intronic primers were designed to amplify the promoter region and exons 1-3 of LEP (primer sequence available on request). There were three amplicons promoter and exon 1 (214 bp), exon 2 (203 bp) and exon 3 (404 bp); none were overlapping. Amplified fragments were purified using Montage PCR Centrifugal Filter Devices (Millipore, Billerica, MA, USA). To screen for sequence variants, amplicons were heteroduplexed to control DNA using the PCR express thermal cycler. Control DNA was obtained from three patients tested for cystic fibrosis mutations, not identified as having CDGP and sequenced to confirm the absence of any known pathogenic sequence variants. Heteroduplex amplicons were passed through denaturing HPLC (dHPLC; WAVE nucleic acid fragment analysis system, Transgenomic, Inc., Glasgow, UK) columns at partially denaturing temperatures (range $55-68^{\circ} \mathrm{C}$ ) with individualized acetonitrile gradients and triethylammonium concentrations that optimized u.v. light absorbance for each amplicon. U.V. absorbance was plotted as a function of retention time taken to elute from a hydrophobic bead cartridge and analyzed with Navigator software, version 1.6.2 (Glasgow, UK).

DNA was sequenced in those with abnormal dHPLC waverforms using BigDye Terminator v3.1 Sequencing kit (Applied Biosystems, Foster City, CA, USA) and run on an ABI 3730 DNA Analyser (Applied Biosystems).

\section{Measurement of leptin and leptin-binding protein}

Serum leptin was measured by IRMA (Diagnostic Systems Laboratories, Webster, TX, USA) and by an in-house RIA in the laboratory of Dr J Kratzsch (Leipzig, Germany) (11). Leptin-binding protein was measured by Dr J Kratzsch, using an in-house ligand-immunofunctional assay (12).

\section{Cloning and production of mutant/wild-type leptin}

One novel LEP sequence variant was identified in the study. In order to assess the functional consequences of this variant, the full-length, wild-type leptin was cloned into TOPO pCRII vector (Invitrogen) from human adipose cDNA. The c.68C $>\mathrm{G}$ variant was created by site-directed mutagenesis and the wild-type and mutant variants subsequently cloned into pDEST14 (Invitrogen). The pDEST14 clones were transfected into BL21-A1 Escherichia coli (Invitrogen) and the resultant leptin purified, refolded and sequenced.

\section{Leptin functional assay}

Biological activity of the wild-type and mutant leptin was tested in human embryonic kidney (HEK293) cells transiently transfected with the leptin receptor long form and a reporter construct containing a Stat3binding element fused to a minimal thymidine kinase promoter and luciferase, as previously described (13). Luciferase activity was measured as previously reported and the effects of wild type, mutant and 1:1 mix of wildtype and mutant leptin were tested over doses ranging from 0 to $100 \mathrm{ng} / \mathrm{ml}$.

\section{Stability of mutant leptin}

In order to test whether the mutant leptin protein may have altered stability in serum, mutant and wild-type 
leptin were spiked into control serum at a concentration of $150 \mathrm{ng} / \mathrm{ml}$. Leptin was measured at $0,1,2,4,8$ and $24 \mathrm{~h}$ using an IRMA (Diagnostic Systems Laboratories).

\section{Results}

Several known single nucleotide polymorphisms (SNPs) and one novel sequence variant were identified in the 78 children with CDGP, using dHPLC. The novel sequence variant, which was found in a heterozygous individual, was identified with direct sequencing as c. $68 \mathrm{C}>\mathrm{G}, \mathrm{pP} 23 \mathrm{R}$. This sequence variant was not found in 112 control DNA samples (taken for cystic fibrosis testing) and the affected amino acid residue (proline) is highly conserved across species (Fig. 1). We hypothesized that the sequence variant may alter the signal peptide cleavage site; however, generation of the mutant leptin demonstrated that cleavage was unchanged (data not shown) and the result was a single amino acid change in the mature leptin molecule.

\section{Case report}

The affected individual was a male referred to the paediatric endocrine service at the age of 15.5 years with concerns about body weight and pubertal progression since the age of 13 years. At presentation, his height was $154 \mathrm{~cm}(-2.2$ S.D.), weight $37.1 \mathrm{~kg}$ $(-2.8$ s.D.) and BMI was $15.6(-2.3$ s.D.). He was in early puberty at Tanner genital and pubic hair stage 3 with testicular volumes of $5 \mathrm{ml}$. His bone age was delayed at 13.5 years $(-1.7$ s.D.) by Greulich and Pyle method. In keeping with his early but established puberty, a GNRH test $(2.5 \mu \mathrm{g} / \mathrm{kg}$ by i.v. injection $)$ demonstrated a basal LH level of 2.4 IU/l with a peak of $26 \mathrm{IU} / \mathrm{l}$ and basal FSH of $3.8 \mathrm{IU} / \mathrm{l}$ and peak of $7.5 \mathrm{IU} / \mathrm{l}$. Magnetic resonance imaging of the brain and pituitary gland was normal. Serum urea, electrolytes and liver function tests were normal. Baseline hormone investigations were normal: serum testosterone $12.4 \mathrm{nmol} / \mathrm{l}$ (pubertal stage P3/G3), thyroid function test - TSH $2.9 \mathrm{mU} / \mathrm{l}$, free thyroxine $16 \mathrm{pmol} / \mathrm{l}$, fasting glucose of $4.8 \mathrm{mmol} / \mathrm{l}$ with fasting insulin of $6.3 \mathrm{mU} / \mathrm{l}$ and a serum IGF1 level of $353 \mathrm{ng} / \mathrm{ml}$ (measured with an in-house assay with a normal range for his age and gender of 232-1000 $\mu \mathrm{g} / \mathrm{l}$. Serum calcium

$\begin{array}{ll}\text { Human } & \text { MHWGTLCGFLWLWPYLFYVQAVPIQKVQDD } \\ \text { Guineapig } & \text { MHWGTLCGFLWLWPYLFYVQAVPIQKVQDD } \\ \text { Cow } & \text { MRCGPLYRFLWLWPYLSYVEAVPICKVQDD } \\ \text { Kangaroo } & \text { MRWGFLCQFLWLWYYLCYVQAVPVQKVQDD } \\ \text { Opossum } & \text { MHCVALCSFLWLCHHLYYTQAVPIRKVQDD } \\ \text { Hedgehog } & \text { MHWGPLCQFLWLWPYLSYLEAVPIERIQDD }\end{array}$

Figure 1 Protein sequence alignment demonstrating high conservation across species for the proline $(P)$ at residue 23 (black background), which is changed to an arginine in the reported family. Signal peptide sequence highlighted in grey.
Table 1 Immunology studies.

\begin{tabular}{lll}
\hline Investigation & Result & Normal range \\
\hline Complement & & \\
C3 (g/l) & 0.72 & $0.83-1.46$ \\
C4 (g/l) & 0.12 & $0.20-0.52$ \\
Immunoglobulins & & \\
IgG1 (g/l) & 7.21 & $4.22-12.92$ \\
IgG2 (g/l) & 2.37 & $1.17-7.48$ \\
IgG3 (g/l) & 0.44 & $0.41-1.24$ \\
IgG4 (g/l) & 0.45 & $<2.91$ \\
Total IgG (g/l) & 11.6 & $7.68-17.78$ \\
Total IgA (g/l) & 1.61 & $0.89-4.46$ \\
Total IgM (g/l) & 1.31 & $0.57-2.60$ \\
Lymphocyte cell surface & & \\
markers & & $7-21$ \\
CD19 (\%) & 19 & $7-21$ \\
CD20 (\%) & 19 & $61-84$ \\
CD3 (\%) & 78 & $32-60$ \\
CD4 (\%) & 56 & $13-40$ \\
CD8 (\%) & 19 & $10-31$ \\
CD16 (\%) & 4 & \\
\hline
\end{tabular}

(2.41 $\mathrm{mmol} / \mathrm{l})$ and phosphate $(1.43 \mathrm{mmol} / \mathrm{l})$ were within the normal range and anti-gliadin, anti-endomysial and anti-thyroid peroxidise antibody titres were normal.

He reported a prolonged period of recovery after minor viral illnesses. Immunology investigations demonstrated marginally low levels of C3, C4 and CD16 positive lymphocytes (Table 1). An initial short synacthen test $(250 \mu \mathrm{g}$ synacthen, i.v. injection) demonstrated a peak cortisol of $295 \mathrm{nmol} / \mathrm{l}$ at $30 \mathrm{~min}$ and a subsequent low dose synacthen test $(1 \mu \mathrm{g}$ synacthen, i.v. injection) demonstrated another suboptimal peak cortisol of $320 \mathrm{nmol} / \mathrm{l}$ at $30 \mathrm{~min}$. ACTH measured at $0900 \mathrm{~h}$ was marginally raised at $67 \mathrm{ng} / \mathrm{l}$ (normal range $5-50 \mathrm{ng} / \mathrm{l}$ ). $\mathrm{CRH}$ stimulation test (1 $\mu \mathrm{g} / \mathrm{kg}$, i.v. injection), undertaken to assess the level of adrenal axis abnormality, demonstrated a peak ACTH of $30 \mathrm{ng} / \mathrm{l}$ (basal $10 \mathrm{ng} / \mathrm{l}$, mean increment in normal children $22 \mathrm{ng} / \mathrm{l}$, range 0-50 (14)) and peak cortisol of $300 \mathrm{nmol} / \mathrm{l}$ (basal $150 \mathrm{nmol} / \mathrm{l}$, mean increment in normal children $295 \mathrm{nmol} / \mathrm{l}$, range 56-580 (14)), both at $45 \mathrm{~min}$, consistent in our laboratory with a positive but not exaggerated response to corticotrophin releasing factor (CRF) at the level of the pituitary, and therefore not supporting a diagnosis of primary or secondary adrenal insufficiency. A hypothalamic aetiology cannot be excluded. He was initially started on replacement hydrocortisone, but felt no benefit. Therefore, he was advised to use hydrocortisone therapy for periods of illness.

He was treated with three i.m. injections of testosterone (100 mg Sustanon) and progressed satisfactorily into puberty with a final height of $172 \mathrm{~cm}$ ( -0.7 s.D.) and adult pubertal staging at age 18.5 years. His weight and BMI at 18.5 years were $49.4 \mathrm{~kg}$ $(-2.5$ s.D. $)$ and 16.7 ( -2.5 s.D. $)$, respectively. He worked as a chef and commented that he lacked appetite, rarely ate a full meal and could go for days 


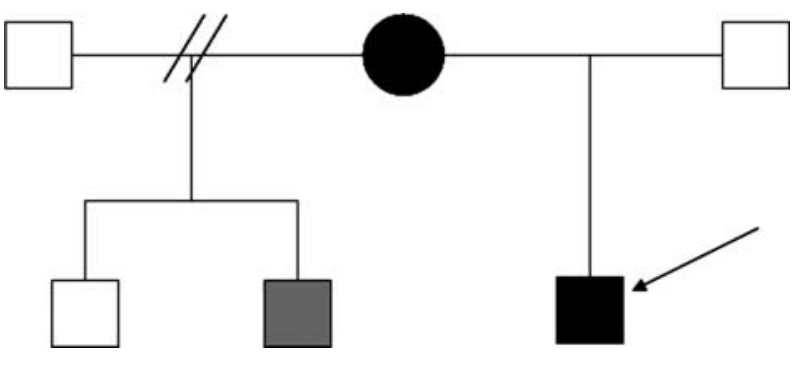

Figure 2 Family tree. The index case was a 15-year-old boy (black, arrow) who presented with poor appetite, low BMI and a delayed puberty. His mother also had a persistently poor appetite and a history of delayed puberty. Both were heterozygous for a novel sequence variant in $L E P$. There was one half-brother (grey) who had a normal phenotype but carried the heterozygous $L E P$ variant. The father and second half-brother had no history of delayed puberty or reduced $\mathrm{BMI}$ and no identified variants in $L E P$.

just picking at food. Importantly, he did not have any disturbance of body image or fear of gaining weight.

His serum leptin was measured at $0.96 \mathrm{ng} / \mathrm{ml}$ using the DSL IRMA, while in the in-house RIA, his serum leptin was undetectable probably due to the sequence variant altering the antibody-binding site. Although normative values are not available for healthy patients of this BMI, extrapolation of regression lines on a plot of BMI SDS versus serum leptin indicates this value would be around the 10th centile. Leptin binding protein was measured at $46 \mathrm{ng} / \mathrm{ml}$ (above the 75 th centile).

Our patient was the only child of non-consanguineous Caucasian parents born at term by spontaneous vaginal delivery, weighing $3800 \mathrm{~g}$. Paternal height was $180 \mathrm{~cm}$ (+0.8 S.D.) and maternal height $154.9 \mathrm{~cm}$ $(-1.2$ s.D.). The patient had two half-brothers via his mother's previous marriage (for family tree, see Fig. 2). Both the mother and one of the half-brothers were also heterozygous for the c. $68 \mathrm{C}>\mathrm{G}$ change. The mother reached menarche at the age of 15 and was thin with a weight of $48 \mathrm{~kg}$ (BMI 18.5). She reported that she had a poor appetite and had to eat high-calorie snacks every day to maintain her weight. The half-brother who was heterozygous for the variant had a normal appetite and weight and did not have any history of delayed puberty. The father had no delay in puberty, no alteration of his appetite or reduced BMI and, in fact, had a heavy build; sequencing of the leptin gene of the father did not reveal a variant or mutation.

\section{Functional assessment of the mutant leptin}

Mutant and wild-type leptin spiked into serum did not decrease in concentration over $24 \mathrm{~h}$ (see Fig. 3). The leptin IRMA consistently detected $\sim 60 \%$ of the leptin spiked into serum.

Using a STAT3 luciferase reporter system, we did not identify any significant difference in the ability of wildtype and mutant leptin to activate the STAT3 reporter gene at concentrations of $6.25,25$ and $100 \mathrm{ng} / \mathrm{ml}$ (see Fig. 4) in three independent experiments. Fold induction of luciferase was not different between a 1:1 mix of wild-type and mutant leptin at total concentrations of $6.25,25$ and $100 \mathrm{ng} / \mathrm{ml}$ and wild-type leptin alone (data not shown).

\section{Discussion}

Here, we report a family where the mother and one son had shown a persistently poor appetite associated with decreased BMI and a history of delayed puberty with both being heterozygous for a novel sequence variant within LEP: one other son was also heterozygous for the same sequence variant but had a normal appetite, BMI and pubertal development. The pattern of inheritance seen would be compatible with a dominant trait with variable penetrance. Sequence variants in other genes such as the leptin receptor or one of the downstream components of the leptin signal transduction system may be required for development of the phenotype described. As this sequence variant was not found within a control group of 112 children nor within 78 CDGP patients also screened for this variant, it must either be a pathogenic variant or a very rare SNP. The high degree of conservation of the amino acid affected supports our view that this is likely to be a pathogenic variant, which may increase the biological

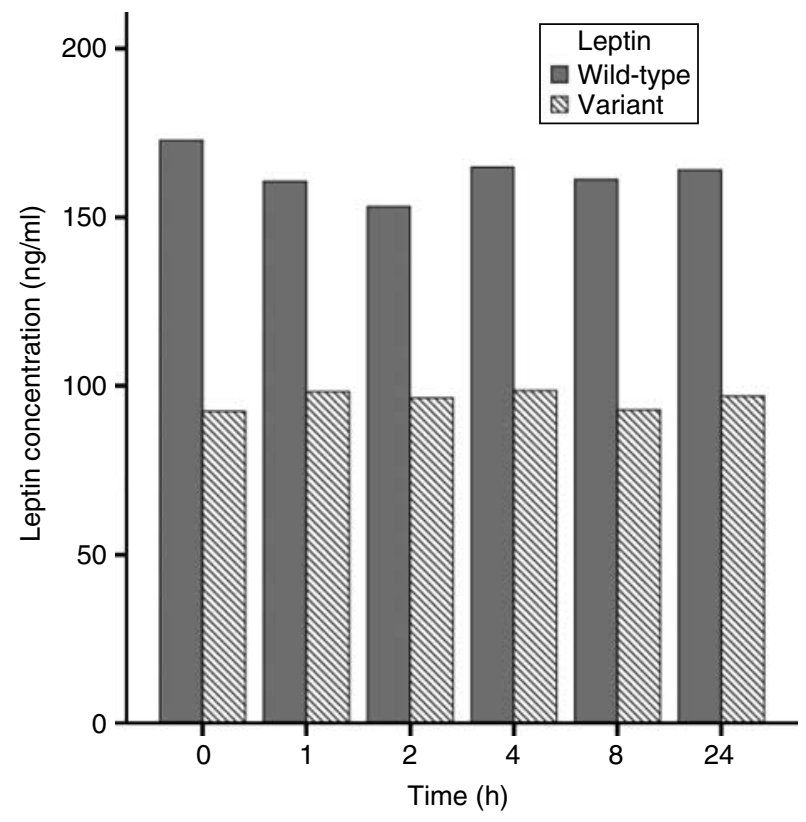

Figure 3 Degradation of mutant and wild-type leptin in serum over $24 \mathrm{~h}$. Wild-type and mutant leptin were spiked at a concentration of $150 \mathrm{ng} / \mathrm{ml}$ into control serum (with a known leptin concentration $<1 \mathrm{ng} / \mathrm{ml}$ ). There was no evidence of degradation either of the mutant or wild-type leptin. The assay consistently detected $\sim 60 \%$ of the mutant leptin spiked into serum. This is likely to be due to one of the antibodies in the assay having a low affinity for the mutant protein. 


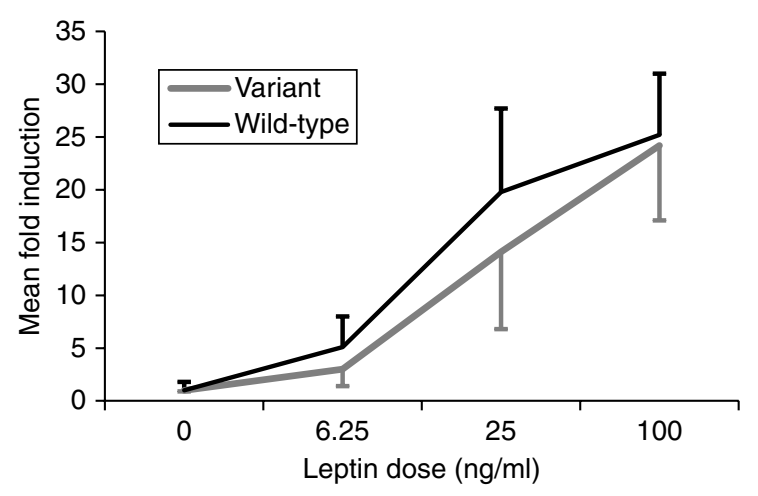

Figure 4 Dose response of luciferase activity to leptin stimulation using either wild type or variant (p.P23R) in HEK293 cells. Cells were transiently transfected with Ob-R plasmid and a Stat3luciferase reporter construct and stimulated with varying doses of leptin. Luciferase activity was measured after $6 \mathrm{~h}$ incubation and was corrected for $\beta$-galactosidase levels, which were used as a transfection control. The results are represented as fold induction over unstimulated cells. There were no significant differences between wild-type and variant ligand at any dose. Error bars represent 1 S.D.

activity of leptin. Autosomal-dominant mutations leading to enhanced biological activity are found in a variety of disorders, including Noonan syndrome (in the MAPK pathway) (15-17), testotoxicosis (in the LH receptor) (18) and in central precocious puberty (in the ligand for GPR 54, kisspeptin) (19). A number of possible mechanisms for this putative increased leptin bioactivity can be proposed: the variant may lead to decreased degradation in serum or an altered balance between free and bound circulating leptin with increased free leptin. Both of these possibilities are unlikely in view of the low endogenous serum leptin level and normal leptinbinding protein levels. The mutant could lead to increased activation of the leptin receptor and hence increased intracellular signalling. We found no evidence of this in our reporter system but this only tested signalling via STAT3, and it is possible that the leptin mutant could differentially stimulate other pathways. Leptin signals through STAT5, S6 kinase as well as PI3K and IRS1 (both via activation of JAK2) (20). It is also known that individual signal transduction pathways may contribute to different components of leptin's action, e.g. the STAT3 pathway contributes to obesity but does not affect linear growth or fertility in mice $(21,22)$; in addition, the short-term effects of leptin on appetite are independent of STAT3 (23). Alternatively, the mutant may occupy the receptor for an increased period, resulting in a more prolonged but not necessarily enhanced signal transduction.

Mutations in several human genes $(1,24-26)$ (LEP, leptin receptor, melanocortin- 4 receptor, prohormone convertase and proopiomelanocortin) have been identified in patients with monogenic obesity syndromes, but data on the genetic causes of thin body habitus are very limited. Screening both obese diabetics and those with anorexia did not identify any pathological LEP mutations $(27,28)$. A recent genome-wide association study in US and Chinese populations identified two SNPs within the only intron of the TRH receptor gene which showed significant association with lean body mass (29), while an association with the vitamin D receptor gene was identified in a cohort of children with idiopathic short stature/CDGP (30).

Two different assays were used to measure serum leptin in our patient. While one assay was unable to detect leptin in the patient's serum, the second assay detected a low level of serum leptin. The low leptin levels are at least in part due to an inability of the assay to detect the mutant leptin, as demonstrated by spiking a known amount of mutant leptin into serum with recovery in the assay being around $60 \%$. This is likely to be due to reduced binding of one of the assay's antibodies to the variant leptin. Low levels of serum leptin are associated with both constitutional delay of growth and puberty $(31,32)$ and with anorexia nervosa $(33,34)$, while serum leptin levels are positively correlated with body fat mass across a wide range of BMI in anorexic, normal weight and obese subjects (34). For patients with CDGP, although absolute levels of leptin are low, levels after adjustment for BMI are increased (35). Patients who are heterozygous for known loss of functional LEP mutations $(76 \%$ of whom had a BMI>30) are known to have low but detectable levels of leptin (36). It is probable that the low serum leptin level in the patient reported here is primarily due to his low BMI. Such low levels of leptin have been reported in patients with anorexia nervosa, where the BMI was similar to that initially reported for our patient (34). We believe that in this patient, the pubertal delay was the result of the very low levels of serum leptin, both normal and mutant, with the increased bioactivity of the latter not being able to compensate in terms of pubertal initiation.

The cause of our patient's adrenal insufficiency is unclear; he displayed normal ACTH and cortisol responses to the CRH test. A hypothalamic aetiology is the most likely. Leptin secretion is pulsatile and there is an inverse relationship between plasma leptin levels and those of ACTH and cortisol (37). It is therefore possible that if the variant leptin had increased bioactivity, this may result in suppression of cortisol secretion.

In conclusion, we report a mother and son who are heterozygous for a novel leptin gene sequence variant with both exhibiting poor appetite, low BMI and delayed puberty (but without fertility problems in the mother). We propose that this is a dominant variant, but functional studies so far have not yet be able to demonstrate enhanced bioactivity of the mutant leptin. Further studies to examine its effects on receptor interactions and other components of the leptin signal transduction system are required. 


\section{Declaration of interest}

P G Murray, A Read, I Banerjee, A J Whatmore, L E Pritchard, A White and P E Clayton have no disclosures relevant to this study.

\section{Funding}

The support of the Manchester National Institute of Health Research (NIHR) Biomedical Research Centre is acknowledged.

\section{Acknowledgements}

The assistance of Dr Julie Trueman, Clinical fellow in Paediatric Endocrinology, is acknowledged. We are very grateful to Dr J Kratzsch (Leipzig, Germany) for measuring leptin-binding protein and also for leptin assay.

\section{References}

1 Montague CT, Farooqi IS, Whitehead JP, Soos MA, Rau H, Wareham NJ, Sewter CP, Digby JE, Mohammed SN, Hurst JA, Cheetham CH, Earley AR, Barnett AH, Prins JB \& O'Rahilly S. Congenital leptin deficiency is associated with severe early-onset obesity in humans. Nature $1997 \mathbf{3 8 7}$ 903-908. (doi:10.1038/ 43185)

2 Isse N, Ogawa Y, Tamura N, Masuzaki H, Mori K, Okazaki T, Satoh N, Shigemoto M, Yoshimasa Y, Nishi S, Hosoda K, Inazawa J \& Nakao K. Structural organization and chromosomal assignment of the human obese gene. Journal of Biological Chemistry 1995 270 27728-27733. (doi:10.1074/jbc.270.46. 27728)

3 Tartaglia LA, Dembski M, Weng X, Deng N, Culpepper J, Devos R, Richards GJ, Campfield LA, Clark FT, Deeds J, Muir C, Sanker S, Moriarty A, Moore KJ, Smutko JS, Mays GG, Wool EA, Monroe CA \& Tepper RI. Identification and expression cloning of a leptin receptor, OB-R. Cell 199583 1263-1271. (doi:10.1016/00928674(95)90151-5)

4 Bray GA \& York DA. Genetically transmitted obesity in rodents. Physiological Reviews 197151 598-646.

5 Lord GM, Matarese G, Howard JK, Baker RJ, Bloom SR \& Lechler RI. Leptin modulates the T-cell immune response and reverses starvation-induced immunosuppression. Nature 1998 394 897-901. (doi:10.1038/29795)

6 Swerdloff RS, Batt RA \& Bray GA. Reproductive hormonal function in the genetically obese (ob/ob) mouse. Endocrinology 197698 1359-1364. (doi:10.1210/endo-98-6-1359)

7 Farooqi IS, Matarese G, Lord GM, Keogh JM, Lawrence E, Agwu C, Sanna V, Jebb SA, Perna F, Fontana S, Lechler RI, DePaoli AM \& O'Rahilly S. Beneficial effects of leptin on obesity, T cell hyporesponsiveness, and neuroendocrine/metabolic dysfunction of human congenital leptin deficiency. Journal of Clinical Investigation 2002110 1093-1103. (doi:10.1172/JCI0215693)

8 Sedlmeyer IL \& Palmert MR. Delayed puberty: analysis of a large case series from an academic center. Journal of Clinical Endocrinology and Metabolism 200287 1613-1620. (doi:10. $1210 / j c .87 .4 .1613)$

9 Banerjee I, Trueman JA, Hall CM, Price DA, Patel L, Whatmore AJ, Hirschhorn JN, Read AP, Palmert MR \& Clayton PE. Phenotypic variation in constitutional delay of growth and puberty: relationship to specific leptin and leptin receptor gene polymorphisms. European Journal of Endocrinology 2006155 121-126. (doi:10.1530/eje.1.02184)

10 Sedlmeyer IL, Hirschhorn JN \& Palmert MR. Pedigree analysis of constitutional delay of growth and maturation: determination of familial aggregation and inheritance patterns. Journal of Clinical Endocrinology and Metabolism 200287 5581-5586. (doi:10. 1210/jc.2002-020862)
11 Kratzsch J, Berthold A, Lammert A, Reuter W, Keller E \& Kiess W. A rapid, quantitative immunofunctional assay for measuring human leptin. Hormone Research 200257 127-132. (doi:10. 1159/000057963)

12 Kratzsch J, Lammert A, Bottner A, Seidel B, Mueller G, Thiery J, Hebebrand J \& Kiess W. Circulating soluble leptin receptor and free leptin index during childhood, puberty, and adolescence. Journal of Clinical Endocrinology and Metabolism $2002 \quad 87$ 4587-4594. (doi:10.1210/jc.2002-020001)

13 Zarkesh-Esfahani H, Pockley G, Metcalfe RA, Bidlingmaier M, Wu Z, Ajami A, Weetman AP, Strasburger CJ \& Ross RJ. High-dose leptin activates human leukocytes via receptor expression on monocytes. Journal of Immunology $20011674593-4599$.

14 Dahl RE, Siegel SF, Williamson DE, Lee PA, Perel J, Birmaher B \& Ryan ND. Corticotropin releasing hormone stimulation test and nocturnal cortisol levels in normal children. Pediatric Research 199232 64-68. (doi:10.1203/00006450-199207000-00012)

15 Pandit B, Sarkozy A, Pennacchio LA, Carta C, Oishi K, Martinelli S, Pogna EA, Schackwitz W, Ustaszewska A, Landstrom A, Bos JM, Ommen SR, Esposito G, Lepri F, Faul C, Mundel P, Lopez Siguero JP, Tenconi R, Selicorni A, Rossi C, Mazzanti L, Torrente I, Marino B, Digilio MC, Zampino G, Ackerman MJ, Dallapiccola B, Tartaglia M \& Gelb BD. Gain-of-function RAF1 mutations cause Noonan and LEOPARD syndromes with hypertrophic cardiomyopathy. Nature Genetics 200739 1007-1012. (doi:10.1038/ng2073)

16 Tartaglia M, Mehler EL, Goldberg R, Zampino G, Brunner HG Kremer H, van der Burgt I, Crosby AH, Ion A, Jeffery S, Kalidas K, Patton MA, Kucherlapati RS \& Gelb BD. Mutations in PTPN11, encoding the protein tyrosine phosphatase SHP-2, cause Noonan syndrome. Nature Genetics 200129 465-468. (doi:10.1038/ ng772)

17 Tartaglia M, Pennacchio LA, Zhao C, Yadav KK, Fodale V, Sarkozy A, Pandit B, Oishi K, Martinelli S, Schackwitz W, Ustaszewska A, Martin J, Bristow J, Carta C, Lepri F, Neri C, Vasta I, Gibson K, Curry CJ, Siguero JP, Digilio MC, Zampino G, Dallapiccola B, Bar-Sagi D \& Gelb BD. Gain-of-function SOS1 mutations cause a distinctive form of Noonan syndrome. Nature Genetics 200739 75-79. (doi:10.1038/ng1939)

18 Reiter EO \& Norjavaara E. Testotoxicosis: current viewpoint Pediatric Endocrinology Reviews 20053 77-86.

19 Silveira LG, Noel SD, Silveira-Neto AP, Abreu AP, Brito VN, Santos MG, Bianco SD, Kuohung $\mathrm{W}$, $\mathrm{Xu} \mathrm{S}$, Gryngarten $\mathrm{M}$, Escobar ME, Arnhold IJ, Mendonca BB, Kaiser UB \& Latronico AC. Mutations of the KISS1 gene in disorders of puberty. Journal of Clinical Endocrinology and Metabolism 201095 2276-2280. (doi:10.1210/jc.2009-2421)

20 Morris DL \& Rui L. Recent advances in understanding leptin signaling and leptin resistance. American Journal of Physiology. Endocrinology and Metabolism 2009297 E1247-E1259. (doi:10. 1152/ajpendo.00274.2009)

21 Bates SH, Stearns WH, Dundon TA, Schubert M, Tso AW, Wang Y, Banks AS, Lavery HJ, Haq AK, Maratos-Flier E, Neel BG, Schwartz MW \& Myers MG Jr. STAT3 signalling is required for leptin regulation of energy balance but not reproduction. Nature 2003421 856-859. (doi:10.1038/nature01388)

22 Piper ML, Unger EK, Myers MG Jr \& Xu AW. Specific physiological roles for signal transducer and activator of transcription 3 in leptin receptor-expressing neurons. Molecular Endocrinology 200822 751-759. (doi:10.1210/me.2007-0389)

23 Hill JW, Williams KW, Ye C, Luo J, Balthasar N, Coppari R, Cowley MA, Cantley LC, Lowell BB \& Elmquist JK. Acute effects of leptin require PI3K signaling in hypothalamic proopiomelanocortin neurons in mice. Journal of Clinical Investigation $2008 \mathbf{1 1 8}$ 1796-1805. (doi:10.1172/JCI32964)

24 Clement K, Vaisse C, Lahlou N, Cabrol S, Pelloux V, Cassuto D, Gourmelen M, Dina C, Chambaz J, Lacorte JM, Basdevant A, Bougneres P, Lebouc Y, Froguel P \& Guy-Grand B. A mutation in the human leptin receptor gene causes obesity and pituitary dysfunction. Nature 1998392 398-401. (doi:10.1038/32911) 
25 Krude H, Biebermann H, Luck W, Horn R, Brabant G \& Gruters A. Severe early-onset obesity, adrenal insufficiency and red hair pigmentation caused by POMC mutations in humans. Nature Genetics 199819 155-157. (doi:10.1038/509)

26 Yeo GS, Farooqi IS, Aminian S, Halsall DJ, Stanhope RG \& O'Rahilly S. A frameshift mutation in MC4R associated with dominantly inherited human obesity. Nature Genetics $1998 \mathbf{2 0}$ 111-112. (doi:10.1038/2404)

27 Hinney A, Bornscheuer A, Depenbusch M, Mierke B, Tolle A, Middeke K, Ziegler A, Roth H, Gerber G, Zamzow K, Ballauff A, Hamann A, Mayer H, Siegfried W, Lehmkuhl G, Poustka F, Schmidt MH, Hermann H, Herpertz-Dahlmann BM, Fichter M, Remschmidt H \& Hebebrand J. No evidence for involvement of the leptin gene in anorexia nervosa, bulimia nervosa, underweight or early onset extreme obesity: identification of two novel mutations in the coding sequence and a novel polymorphism in the leptin gene linked upstream region. Molecular Psychiatry 19983 539-543. (doi:10.1038/sj.mp.4000394)

28 Maffei M, Stoffel M, Barone M, Moon B, Dammerman M, Ravussin E, Bogardus C, Ludwig DS, Flier JS, Talley M, Auerbach S \& Friedman JM. Absence of mutations in the human OB gene in obese/diabetic subjects. Diabetes 199645 679-682. (doi:10.2337/diabetes.45.5.679)

29 Liu XG, Tan LJ, Lei SF, Liu YJ, Shen H, Wang L, Yan H, Guo YF, Xiong DH, Chen XD, Pan F, Yang TL, Zhang YP, Guo Y, Tang NL, Zhu XZ, Deng HY, Levy S, Recker RR, Papasian CJ \& Deng HW. Genome-wide association and replication studies identified TRHR as an important gene for lean body mass. American Journal of Human Genetics $2009 \mathbf{8 4}$ 418-423. (doi:10.1016/j.ajhg.2009. 02.004)

30 Dempfle A, Wudy SA, Saar K, Hagemann S, Friedel S, Scherag A, Berthold LD, Alzen G, Gortner L, Blum WF, Hinney A, Nurnberg P, Schafer H \& Hebebrand J. Evidence for involvement of the vitamin $\mathrm{D}$ receptor gene in idiopathic short stature via a genome-wide linkage study and subsequent association studies. Human Molecular Genetics 200615 2772-2783. (doi:10.1093/ $\mathrm{hmg} / \mathrm{ddl} 218$ )
31 Bideci A, Cinaz P, Hasanoglu A \& Tumer L. Leptin, insulin-like growth factor (IGF)-I and IGF binding protein-3 levels in children with constitutional delay of growth. Journal of Pediatric Endocrinology $\mathcal{E}$ Metabolism 200215 41-46.

32 Gill MS, Hall CM, Tillmann V \& Clayton PE. Constitutional delay in growth and puberty (CDGP) is associated with hypoleptinaemia. Clinical Endocrinology 199950 721-726. (doi:10.1046/j.13652265.1999.00736.x)

33 Misra M, Miller KK, Almazan C, Ramaswamy K, Aggarwal A, Herzog DB, Neubauer G, Breu J \& Klibanski A. Hormonal and body composition predictors of soluble leptin receptor, leptin, and free leptin index in adolescent girls with anorexia nervosa and controls and relation to insulin sensitivity. Journal of Clinical Endocrinology and Metabolism 200489 3486-3495. (doi:10.1210/jc.2003032251 )

34 Tagami T, Satoh N, Usui T, Yamada K, Shimatsu A \& Kuzuya H. Adiponectin in anorexia nervosa and bulimia nervosa. Journal of Clinical Endocrinology and Metabolism $2004 \mathbf{8 9}$ 1833-1837. (doi:10.1210/jc.2003-031260)

35 Wudy SA, Hagemann S, Dempfle A, Ringler G, Blum WF, Berthold LD, Alzen G, Gortner L \& Hebebrand J. Children with idiopathic short stature are poor eaters and have decreased body mass index. Pediatrics 2005116 e52-e57. (doi:10.1542/peds. 2004-1684)

36 Farooqi IS, Keogh JM, Kamath S, Jones S, Gibson WT, Trussell R, Jebb SA, Lip GY \& O'Rahilly S. Partial leptin deficiency and human adiposity. Nature $2001 \mathbf{4 1 4} 34-35$. (doi:10.1038/35102112)

37 Licinio J, Mantzoros C, Negrao AB, Cizza G, Wong ML, Bongiorno PB, Chrousos GP, Karp B, Allen C, Flier JS \& Gold PW. Human leptin levels are pulsatile and inversely related to pituitary-adrenal function. Nature Medicine 19973 575-579. (doi:10.1038/nm0597-575)

Received 29 November 2010

Accepted 4 February 2011 